\title{
Fundamentalism: examining the role of public reason in 'non-liberal' approaches to 'unreasonable' doctrines
}

\author{
Matthew T. Johnson ${ }^{1}$ and Simon Mabon \\ Department of Politics, Philosophy and Religion, Lancaster University, Lancaster, UK
}

\begin{abstract}
In this article, we examine ways in which critics of liberalism come to adopt, without acknowledgement, 'liberal' forms of public reason in responding to homogenising tendencies of fundamentalist doctrines. We focus on the divergent approaches of John Gray and Slavoj Žižek, arguing that the former upholds a comprehensive form of liberalism, while the latter upholds a political form popular among policy makers who endorse a 'fundamentalism'/'extremism' dichotomy. We argue that the latter fails to recognise that 'philosophical' unreasonableness often translates into political unreasonableness. Examining these non-liberal approaches not only indicates the apparent value of reason as reciprocity, it also supports a long-held charge against liberalism: that it is not able to uphold its promise of accommodating radical forms of diversity.
\end{abstract}

Keywords: Fundamentalism; extremism; liberalism; public reason

The term 'fundamentalism' looms large over our most significant global problems. Whether it be religious, market or other 'fundamentalist' doctrine, there is concern that believing in a narrow set of values or a singular truth or doing something to an extreme is, in some way, the contemporary source of conflict and harm. Yet, etymologically, this ubiquitous term has a narrow meaning, only hinting at the broader, pejorative and political context within which it is now deployed.

Historically, fundamentalism emerged as a point of reference for American Presbyterians who sought to denounce liberal scriptural interpretation in favour of a return to five fundamentals of faith (see Kippenberg, 1991, 128): divine, infallible 'Biblical inspiration'; the Virgin birth; the Crucifixion as Christ's atoning for humanity's sin; his bodily resurrection and the objectivity of Christ's miracles (see Ammerman, 1987). This notion of fundamentalism as internal and (at least potentially) apolitical, defined by belief in the infallible word of God, renders all Muslims, by virtue of the Shahada, fundamentalists, yet leaves proponents of 'neoliberalism', who preach submission to quasi-supernatural processes of the market, untouched. As Martin Marty $(1988,15)$ argues, 'The term eludes precise definition', but it 'is clear that the original dictionary definitions which connected it with concepts of biblical inerrancy are obsolete'. In the edited collection, Fundamentalism in Comparative Perspective, Kaplan notes that 'fundamentalism will be defined anew by practically every one of this book's authors' (Kaplan, 1992, 5). Masalha and Hayes $(2006,98)$ add that 'There is no agreed definition of the concept', though 'it has often been used pejoratively when talking about conflicts in the Middle East and elsewhere'. This is apparent in Nagata's $(2001,495)$ anthropological account, which claims that 'the term is used for different purposes and effect by different constituencies, from outsider to insider ("true believer"), enemy to sympathizer, "detached" scholar to sensational public or media'.

This ambiguity is, though, deeply unsatisfactory since, if 'fundamentalist' tendencies really are the cause of human misery, we need seriously to understand the constituent features of those tendencies in order to respond effectively. However, this apparent ambiguity may owe

\footnotetext{
${ }^{1}$ Matthew T. Johnson m.johnson@lancaster.ac.uk
} 
less to radical differences in understanding and more to differences in articulation. In this article, we examine the often-unacknowledged role of public reason in 'non-liberal' understandings of fundamentalism to evaluate two public policy approaches to fundamentalist doctrines.

We proceed by demonstrating that popular, quantitative accounts of fundamentalism, such as that of Bruce Lincoln, which hold that fundamentalist doctrines are those that permeate all elements of a person's life, actually rely upon an unexplored qualitative concern for such doctrines' approaches to other groups. We explore this element through the work of two key and divergent critics of liberalism - John Gray and Slavoj Žižek - who uphold, implicitly and, presumably, unintentionally, liberal, Rawlsian concern for public reason as means of identifying the essence of fundamentalism. Importantly, the two thinkers advance, respectively, responses compatible with comprehensive and political liberal positions. There is reason, we argue, to believe that Gray's approach leaves scope for challenging the philosophical basis of 'fundamentalist' doctrines, while Žižek's appears to uphold a distinction between 'good' and 'bad' fundamentalisms or 'fundamentalists' and 'extremists' popular in 'liberal' public policy discourses. We evaluate the plausibility of these two approaches through engagement with key anthropological and sociological studies of 'fundamentalist' doctrines, such as A Comparative Study of Jewish, Christian and Islamic Fundamentalist Perspectives on Jerusalem and The Fundamentalism Project. Such studies give us reason to believe that tackling politically 'unreasonable' doctrines while leaving philosophically unreasonable doctrines alone is, in many cases, problematic.

We argue that such a conclusion poses problems for both liberals and critics of liberalism, such as Gray and Žižek, who wish to uphold pluralism. By adopting public reason, the latter demonstrate the value of the approach, while also demonstrating its limitations, perhaps supporting a long-held charge against liberalism: that it is not able to uphold its promise of accommodating radical forms of diversity. As such, our account, which is not motivated by any particular liberal disposition (indeed, the primary author is heavily influenced by Marxism - see Johnson 2012), highlights internal contradictions in both liberal and nonliberal approaches. We argue that understanding and dealing with these two sets of internal contradictions is important for liberals and non-liberals alike in terms of dealing openly and honestly with perhaps the key policy challenge of the day. We begin by outlining public reason, since it is this liberal notion that has come to inform a range of approaches.

\section{Liberalism and public reason}

Liberalism has been marked by the Lockean tradition of dividing public and private spheres (Locke 1983, 26), with disagreements about behaviour in the latter set aside in the former through the deployment of toleration between citizens (Locke 1983, 51; 28). Traditionally, to tolerate, one has to a) find a belief or practice morally objectionable, b) have the capacity to prevent it and c) exercise virtuous restraint in not preventing it (see debate in Horton 1996). Liberalism has also been shaped by the Kantian belief that humans are uniquely rational beings (Kant 2005, 104-107) that ought to be treated as ends rather than means and ought to develop moral law according to an objective evaluation of needs and interests (Kant 2005, 102). To this end, Kant upholds the categorical imperative, which allows principles to be developed according to 'motives valid for every rational being', rather than selfish 'impulsions' (Kant 2005, 105). The test of the categorical imperative, and 'the general canon for all moral judgment of action', is that 'We must be able to will that a maxim of our action should become a universal law' (Kant 2005, 100). If we are unable to conceive the universal application of our actions, we understand them to be subjective and unreasonable. This thought experiment forces us to challenge our naturally 'unsociable' character (Kant, 1991, 44; 46) and makes explicit our attempts to constrain others, while freeing ourselves as citizens (Kant 2005, 101). In this 
vein, liberals have regarded 'public reason' as central to the development of rules by which to govern the public sphere. The notion has, however, been taken to mean subtly different things. While the likes of Habermas (1998) have connected public reason to the discursive development of shared norms, the likes of Rawls have understood the term to denote means by which to advance general political principles capable of enabling radically different 'comprehensive doctrines' to be pursued.

Comprehensive doctrines provide the philosophical resources by which to develop understandings of right and wrong and good and bad. Individuals accrue comprehensive doctrines from the acculturation inherent in their development in particular circumstances as human beings. Because people's backgrounds differ, so too do their doctrines. The questions to which these doctrines respond do not necessarily admit of any clear answers capable of resolving disagreement. If a state promotes any one particular comprehensive doctrine, those who pursue other, contradictory doctrines are necessarily disadvantaged and face the prospect of being used as means to the ends of others (see Rawls 1988). For Rawls, this is of grave concern, since his Kantian inheritance means that he believes that individuals ought to be free and equal and treated with respect as ends in themselves, capable of developing lives in accordance with their comprehensive doctrines free from the paternalism of other groups or political bodies (see Rawls 1975). This leads him to argue that citizens have a shared interest in advancing political systems that remain neutral between doctrines, that prioritise the right over the good, and that uphold legal and political equality in order that different doctrines can be pursued. In this respect, whatever particular comprehensive doctrine an individual upholds, there is a general public interest in upholding the same system of political liberalism.

The result is 'a political conception of justice' restricted to "the domain of the political" and its values' that 'can be endorsed by widely different and opposing though reasonable comprehensive doctrines' (Rawls 1996, 38). Although there are numerous different contexts within which Rawls deploys a concept of 'public reason', the one of significance to this article lies in the notion of reciprocity between citizens within such an order (see Rawls 1971 and Quong 2013). This 'overlapping consensus' stems directly from public reason in action, identifying the general interests of citizens and articulating reciprocal means of co-existence between those citizens (Rawls 1996, 387). Toleration is particularly important in this respect since, as a civic virtue, it instils in individuals reason to challenge their impulse to suppress beliefs and practices with which they disagree. It upholds 'the fact of reasonable pluralism', in which comprehensive doctrines are deemed 'reasonable provided they recognise the essentials of a liberal democratic regime and exhibit a reasoned ordering of the many values of life (whether religious or nonreligious) in a coherent and consistent manner' (Rawls 2001, 87).

However, the implications of this position have long been debated. Kelly and McPherson (2001) argue that there are two elements of unreasonableness that call for different instances and courses of action: a) philosophical unreasonableness, in which a doctrine is informed by illogical or groundless belief, but which may or may not otherwise uphold public reason and b) political unreasonableness, in which a doctrine actively rejects public reason. In a position supported by Quong $(2011,295)$, they argue that the state ought not to intervene in the former, but can intervene in the latter. This stance is illustrated by Macedo's (1995) consideration of the case of Mozert v. Hawkins (1983), in which 'born again' Christian parents complained about the 'even handed' treatment of religions in public education. The complaint, in Macedo's (1995, 471) words, was not that a particular doctrine was being promoted (so long as that doctrine was Evangelical Christianity, the parents would have no complaint), but 'that the program taken as a whole exposed the children to a variety of points of view and that this very exposure to diversity interfered with the free exercise of the families' religious beliefs by denigrating the truth of their particular religious views'. In effect, the de facto necessity of public education entailed a de facto constraint on the ability of parents to shield children from 
ideas regarded as deviant or objectionable by their parents. Macedo $(1995,474)$ correctly notes that, in political liberal terms, it is unacceptable for the state to inflict comprehensive 'Millian individuality' which ought properly to be 'regarded as one more sectarian view among others'. It is, however, legitimate for a political liberal system to promote toleration, since this is an essential means of fostering co-existence. The Evangelicals can be seen to be reasonable, so long as they resist transforming their contempt for others into political action and accept that, as citizens, they have a responsibility to uphold the right of others to pursue their comprehensive doctrines as the basis of their own liberty.

Political liberal bodies can intervene legitimately against those who do not recognise the general interest in reciprocity, since such intervention is aimed at resisting, rather than promoting, attempts to establish politically a particular comprehensive doctrine. This concern for reasonableness as reciprocity has, we argue, come to inform even 'non-liberal' understandings of fundamentalism. To demonstrate this impact, we need, first, to illustrate the way in which popular, supposedly quantitative, notions of fundamentalism as maximalism are actually grounded in qualitative commitments

\section{Maximalism: The permeation of faith into every sphere of life}

For Bruce Lincoln (2006), fundamentalists are those whose faith permeates all aspects of their lives. They are 'maximalists', whose doctrine is 'comprehensive' in the truest sense, believing that people universally must orient themselves around adherence to a truth claim. Those who do are worthy and those who do not are unworthy. By way of illustration, Lincoln (2006, 1932) highlights the bifurcatory rhetoric of both Osama bin Laden and George W. Bush in the wake of 9/11. Bin Laden recognises God, highlights his beneficence and claims divine ordination for the act. He creates a distinction between believers and unbelievers, which is pursued first in terms of self-identification as Muslim and non-Muslim, and then through reference to the specific practices which identify one as being Muslim or non-Muslim and then, more broadly, non-white or white. Bush's religious rhetoric is tempered by the tensions between the US' secular and religious and monist and pluralist traditions. However, he still recognises God, asserts his beneficence and claims divine ordination for the US' response to 9/11. He also introduces binary distinctions of 'good' and 'evil', 'civilised' and 'uncivilised' and 'us' and 'them', alluding to Biblical passages, converting 'secular political speech into religious discourse' and investing 'otherwise merely human events with transcendent significance' (Lincoln, 2006, 32). The purpose of this is to appeal, subtly, to those who adhere to a maximalist 'construction of all values as religious' (Lincoln, 2006, 32): the American Evangelical right which has, in contrast to the defensive, isolationist claims of Mozert vs Hawkins, called for prayers in schools, a return to Biblical fundamentals and the restoration of Christianity to the position it enjoyed in Puritan New England. At an abstract level, these Christian maximalists are quantitatively similar to Islamist maximalists insofar as they wish to see faith permeate all spheres of life (Lincoln, 2006, 60), even though the nature of those lives may be very different.

This account leaves, however, ambiguity. 'Maximalism' alone does not explain fully Lincoln's concern for his two examples, since it is clear that a significant number of apparently anodyne comprehensive doctrines believe in binary distinctions and the permeation of the doctrine into all elements of a person's life. For example, Lincoln does not appear concerned with the case of a progressive Anglican Priest, or even the Mozert parents (so long as they are restrained isolationists), who still believe in good and evil, but are otherwise committed to civic virtues that render the comprehensive doctrine compatible with diversity. In this regard, Lincoln's 'maximalism' owes less to a quantitative analysis and more to an unacknowledged qualitative concern for the ways in which doctrines call for the dissolution of the distinction between the public and private spheres. The fact that this can be adduced only through 
supposition indicates deficiency in such 'common sense' approaches. To appreciate the extent to which qualitative concern for reasonableness as reciprocity has informed contemporary understandings, we need to examine the approach of Gray, who provides an account of fundamentalism as inhuman fetishisation and infliction of value.

\section{Gray: convergence on values}

In thinking about the values that underpin lives, Gray has argued that 'Common experience and the evidence of history show human beings thriving in forms of life that are very different from one another. None can reasonably claim to embody the flourishing that is uniquely human' (Gray, 2000, 21, our emphasis). This 'fact of pluralism' denotes belief that human existence is oriented around values that are objective, universal and multiply realisable, but incommensurable, often uncombinable and naturally conflictual. Humans have basic biological, animal and social needs that must be satisfied if they are to do and be well (Gray, 1997, 58). Values provide means of responding appropriately to the different resources and challenges of different circumstances so as to satisfy needs and achieve flourishing in each context (Gray, 2004b, 1-8; 41-48). Sometimes the value choices we need to make are identifiable through reason, but at other times they are dependent on intuitive, speculative 'radical choice' (Gray, 2000, 65). Whatever the situation, we need to be pragmatic, rather than dogmatic, understanding that different contexts call for different value sets (see Gray, 2003, xi; Gray, 2002, 127-128, Johnson 2013). People guided by 'good', non-fundamentalist value commitments prioritise human well-being and strive to stave 'off disaster from day to day' by overcoming short-sighted 'fecklessness' (Gray, 2004b, 30; 31).

Gray's main target is a liberalism destructively unaware of its limitation as one way of life among many and of the broader need to prioritise the good over the right (Gray 2000, 21; 135). However, despite his lengthy criticisms of liberalism, he endorses the development of political systems grounded in reciprocity between holders of different comprehensive doctrines. To this end, he supports 'a modus vivendi among goods and evils' attractive to 'all or' 'nearly all' because it enables radically divergent ways of life to flourish. Such modus vivendi seek, not to promote 'any particular value', but to enable 'conflicts among values to be negotiated' (Gray 2000, 133; 135; 133). There are, though, many 'fundamentalist' doctrines that remain committed to the illusion that their value sets are the only legitimate means of realising the good and that sustenance of those sets should be prioritised over human wellbeing (Gray, 2003, xi-xv; 2004a, 1-58; 2004b, 1-8). These doctrines neglect core animal and human needs (Gray, 2004a, 4) and can be identified equally in al Qaeda-inspired Islamism, Nazism and the 'Enlightenment faiths' of communism and neo-liberalism (see Gray, 2004a, 4). They are necessarily political: having identified their value sets as exclusively legitimate, they use power to impose their realisation. In doing so, they inflict harm, not simply by neglecting needs but, also, by eradicating the possibility of living according to alternative value sets that might foster greater levels of well-being within particular circumstances. They seek convergence on value sets, failing to recognise objective truth - 'the fact of pluralism' - and denying humanity in the process (see Gray, 2000, 22). Highlighting the deficit in Lincoln's account, Gray holds that fundamentalists are not just concerned that values permeate their lives 'maximally', but that their values (and those values may differ from fundamentalist to fundamentalist) are the only values deemed worthy of life (Gray, 2015).

As they do this, they emphasise the importance of social goods, such as security, threatened by the dislocation and atomisation of modernity. Given that Gray seeks actively to reject liberalism (Gray 2000, 21; 135), we might expect him to advance alternative means of accommodating threatened ways of life. However, his value pluralist account of modus vivendi follows a similar course to that of Rawls' reasonableness as reciprocity in its belief that groups ought to recognise one another's interest in co-existence. In order to deal with the pathology 
of fundamentalism, there is implicit scope, in Gray, for revealing the 'truth' of value pluralism - of leading fundamentalists 'out of their caves and inform[ing] or remind[ing] them of what the world is really like' (Jones, 2006, 196). Prima facie, this appears at least compatible with attempts to promote public reason, with Gray presuming that people can converge on truth, without ever converging on values and without ever regarding others' value sets as being inferior in abstraction from context. However, as Jones $(2006,196)$ notes, revealing the 'truth of pluralism' not only fosters political reasonableness, it also changes, fundamentally, the nature of the doctrine itself by removing illusions of exceptionalism and the fetishisation of value sets. It does not leave doctrines unchanged, even if Gray critiques such homogenising forces in liberalism. As such, if we afford Jones' understanding weight, the revelation of the 'fact' of pluralism does not simply add toleration to groups' beliefs, as in the case of public education in Mozert vs Hawkins, it actively alters the core tenets of their doctrines.

While we do not suggest that Gray endorses liberalism as a whole, there are grounds to suggest that he regards public reason as a precondition of modus vivendi and views an inability to accept reasonableness as reciprocity as the defining and intolerable characteristic of fundamentalism. However, unlike political liberals like Kelly and McPherson (2001), he does not believe that philosophical unreasonableness can be quarantined from political unreasonableness. As such, having been driven by concern for liberalism's capacity for homogenisation, Gray opens up the possibility of advancing beliefs attendant to reason as reciprocity in almost comprehensive forms. This is, though, problematic on a number of grounds, since 'fundamentalisms' are often posited as emerging as, or becoming politically unreasonable in response to, their being challenged. Such concern lies at the heart of Žižek's distinction between confident, contemptuous 'good' fundamentalists and diffident, envious, 'bad' fundamentalists.

\section{Žižek: convergence on truth}

Žižek's (2013a; 2014) work, though beyond simple classification, has famously been influenced by Marx, Hegel and Lacan. However, his account of fundamentalism demonstrates synergies with political liberal approaches. Fundamentalism's defining feature is the way in which capturing objective, universal truth is seen to provide specific groups with transcendental authority. The 'good' fundamentalist has unwavering belief in a truth that has significance beyond individual human beings. This truth conforms to, but cannot be reduced to, a value set. 'Good' fundamentalism induces a sense of calm among believers, since it provides assurance in superiority. In identifying 'good' fundamentalists, Žižek (2014) highlights the rank indifference of Tibetan Buddhists or Amish to other ways of life that they regard, confidently, as inferior (see also Macedo 1995, 472). They have no need to convert non-believers or to alter the world universally to make it conform to their beliefs. They wish simply to be able, as true believers, to live according to the truth or, failing that, to uphold their internal belief (see Berlin, 2002, 135-136) in order to achieve whatever transcendental ends they pursue. Despite their disdain for others, these 'fundamentalisms' are 'reasonable', apolitical doctrines. They view those who seek enlightenment in other ways of life with confusion. Central among 'the confused' are Islamist militants, many of whose lives, paradoxically, are grounded centrally in Western thinking and experience. We misunderstand their thinking when we diagnose their schemes as conservative: 'The problem is not cultural difference (their effort to preserve their identity), but the opposite fact that they already like us, that, secretly, they have already internalised our standards and measure themselves by them' (Žižek, 2014).

In this sense, although ISIS members, for example, are fundamentalists in Gray's thinking by virtue of their desire to promote a narrow value set, they are not 'good' fundamentalists in Žižek's psychological sense, since they lack authentic faith in their own superiority. It is this diffidence that leads 'bad' fundamentalists, like ISIS, to seek violently to 
alter the world and to be threatened, rather than pacified, by revelation of the 'truth' of pluralism. They are compelled to bestow support on an ever-decreasing number of 'true' believers who maintain a veneer of belief in light of all emerging evidence to the contrary (see Wood 2014; 2015). Because truth is so central to fundamentalist comprehensive doctrines, followers develop intricate means of understanding events through unfalsifiable lenses and shaping the world to ensure the dominance of believers and the suppression of non-believers. ISIS, of course, attributes defeat to the impure human application of God's will and responds by implementing ever more fully that 'will' on populaces (see Wood 2015). This is because, if particular beliefs no longer correspond to 'the truth', the exalted status of groups is lost. For Žižek, this is a trait that permeates non-faith groups.

Recounting the rhetoric of 20th century Marxists, Žižek (2013a) notes the cognitive dissonance in secular fundamentalisms. Some Marxists have, historically, sought to distance themselves from the failures of Marxism by arguing that Leninism, Stalinism or other forms of state socialism were human perversions of Marx's scripture. Were Marxian tenets applied purely, they would lead humanity to a perfected condition. This phenomenon is also evident in neo-liberal belief in the exalted status of Wall Street or The City and the scriptural importance of economists and their unfalsifiable approaches to the Global Finance Crisis 2007-2008. Rather than regarding the crisis as a failure of the market, they view it as a failure by governments to implement the market effectively - the result of the overeager welfare state undermining the natural status of entrepreneurs and financiers, rather than of the market itself. The problem, as Žižek (2013a) notes, is that 'When we dismiss the failures of market capitalism as accidental mishaps, we end up in a naive "progress-ism" that sees the solution as a more "authentic" and pure application of a notion, and thus tries to put out the fire by pouring oil on it'.

This 'bad' fundamentalist praxis is distinguishable from 'good' praxis on account of the resilience of belief and the need for universal, totalising shifts in humanity. Without changing humanity in its entirety, claims cannot be validated and associated goods realised. Accordingly, fundamentalism, contra Gray, is contingently, rather than intrinsically harmful. However, like Gray, the examples of 'bad' fundamentalism in Žižek seem to share two key features: their desire or need for universal transformations of the world and their inability to accept reasonableness as reciprocity. In this sense, 'good' fundamentalist doctrines appear apolitical. They are compatible with other reasonable doctrines insofar as they accept pluralism and, at least in Žižek's examples, appear to make no broader demands as to the nature of political systems. They are capable of upholding reasonableness as reciprocity, even or especially with those they hold in contempt. 'Bad' fundamentalisms appear wholly unreasonable insofar as they are unwilling to accept pluralism and demand that political systems promote, exclusively, their interests. In this sense, like Gray, Žižek's means of evaluating comprehensive doctrines appears to coincide with at least elements of Rawls' concern for public reason, while his 'good'/'bad' distinction corresponds to the oft-cited 'fundamentalism'/'extremism' distinction often deployed by liberal Governments.

Žižek's response to 'bad' fundamentalism is intended to be robust, but appears confused, contradictory and ultimately more politically liberal than may seem. He seeks to 'formulate a minimum set of norms obligatory for everyone that includes religious freedom, protection of individual freedom against group pressure, the rights of women, etc. - without fear that such norms will appear "Eurocentric"', insists 'unconditionally' on 'tolerance of different ways of life', and, 'if norms and communication don't work', asserts that 'the force of law should be applied in all its forms' (Žižek 2015). That sounds compatible with public reason and a political liberal constitution, but he also states that 'Tolerance as a solution (mutual respect of each other's sensitivities) obviously doesn't work', advancing what looks like defence of a comprehensive liberalism that endorses particular goods and disavows 
toleration as a civic virtue. However, this description of 'tolerance' is actually much closer in content to toleration as recognition advanced by the likes of Galeotti (2002). In Galeotti's view, people do not have to object to a practice to tolerate; they must respect or recognise its importance to the bearer, shifting conceptually from virtue as restraint in the face of objection to virtue as appraisal. While Žižek's work is broad brush and short on subtlety, it appears that he regards this more modern account of toleration as having failed and the more traditional, classical liberal account grounded in mutual dislike as being of enduring value to political action. As such, Žižek would, unlike Gray, leave the Mozert parents' doctrine alone, fostering commitment to toleration through, for example, civic education. If that is the case, whatever other positions he may hold on separate issues, Žižek upholds a position on fundamentalism that is at least compatible with reasonableness as reciprocity and which resembles closely political liberal commitments to tacking political, but not philosophical, unreasonableness.

Having established that both Gray and Žižek appear to uphold reasonableness as reciprocity as the basis for their understandings of fundamentalism, it is necessary to consider the implications of their respective approaches to dealing with the political problems engendered by fundamentalism.

\section{Evaluating the distinction between 'good' and 'bad' fundamentalism}

The contrast between Gray's and Žižek's positions reflects core public policy debates on fundamentalism. In effect, Žižek's 'good'/'bad' distinction, which Gray seems to reject, reflects the popular 'fundamentalist'/'extremist' distinction that has been adopted by liberal Governments in working with organisations that uphold 'fundamentalist' philosophical doctrines, but are opposed to 'unreasonable', 'extremist' political praxis. There are ways in which the anthropological and sociological literature on 'fundamentalisms' calls this philosophical/political unreasonableness distinction into question and raises the prospect of 'disparate burdens' being placed on fundamentalist doctrines to uphold reasonableness as reciprocity.

In support of examples given by Gray and Žižek, a variety of studies have suggested that fundamentalist doctrines are often monotheistic. There are several reasons for this. In addition to the transcendental universalism highlighted by Gray and Žižek, there is belief, in some accounts, that fundamentalism can only be applied to the Abrahamic faiths since it is the presence of divine scripture that enables groups to identify and seek to uphold or return to a series of central tenets and interpret events in modern contexts through those lenses (see Antoun 2001). In keeping with Žižek's notion of convergence on truth, Masalha and Haynes (2006, 104), the project leaders of A Comparative Study of Jewish, Christian and Islamic Fundamentalist Perspectives on Jerusalem, note that followers believe 'that they possess special and direct access to transcendental, absolute truth.... couched in ideologically absolute and uncompromising perspectives'. Moreover, they share concern for contested Holy places, fostering forms of militancy from belief that monopolising political power is an essential means of realising divine prophesies, rendering 'spiritual/religious and secular/political dimensions' inseparable (Masalha and Haynes 2006, 99-100). For example, Masalha and Haynes (2006, 100-101) argue that, while some claims to exclusivity of the 'Holy City' emerged historically through conflicts such as the 1967 Six-Day War, many other claims were mythical and ahistorical. Such phenomena are also evident in ISIS' obsession with Dabiq as a site of conflict (see Wood 2014). In this regard, the notion of the 'fundamentalist'/'extremist' or 'good fundamentalist'/'bad fundamentalist' dichotomy is simply naïve. It is difficult to be an Abrahamic monotheist without having the potential for political action of consequence to reasonableness as reciprocity.

Dorraj, however, has argued that some monotheistic doctrines, such as Orthodox Christianity, have always upheld a theological distinction - in parallel with the 
philosophical/political reasonableness distinction - between being a Christian and acting politically, rendering 'unto Caesar that which was Caesar's and... unto God what was God's'. He contrasts these apolitical forms of Christianity with Judaism and Islam which, from the beginning, have regarded 'the social and political order as integral parts of the sacred' (Dorraj, 1999, 229). In Dorraj's account, for Christianity to follow such a course, it had to be transformed, in one instance, by liberation theologians into a collectivist faith in which the interests of the group were more important than the individual. An important stimulus for this shift in thinking was the influence of Marxism, with its necessary commitment to action (Min $1989,5)$. Such a reading of Christianity neglects the fact that the faith's relationship with political structures has been apparent since its adoption by Rome. It appealed to the Roman political apparatus not simply because it offered the capacity for different ethical codes in political and personal action (permitting 'sin' in one, but not the other), but also because its monotheism provided philosophical support for political centralisation of authority (see Richards 1979, 15). In many cases since, Christians were ruled by Christian rulers who upheld Christian doctrines and so did not need to establish their doctrines further. Until fairly recently, most sects of Christianity simply were not Žižek's 'good' fundamentalists, believing that their specific sects had to be established as organs of state in order for the good to be upheld.

As noted above, beyond monotheism, Gray (2015) has argued that, while not connected with divine scripture or place, some similar tendencies towards scripturalism, monism, universalism, monopolisation of power and transcendent goods are apparent in Enlightenment 'secular faiths' (see Kippenberg, 1991, 129). For some Marxists and neo-liberals, there are scriptures which elicit quasi-theological responses from believers and provide the basis, as Žižek (2013b) has argued, for unfalsifiable analyses which call for unreasonable political actions. They share, with Christians and Muslims, belief in 'time as millennial and messianic', in which 'human history will come to a miraculous end with the ultimate triumph of the good over evil' (Weinberg and Pedahzur, 2004, 5-6), though through forces which, while quasisupernatural and esoteric, are not divine (see Gray, 2015). Gray states that

Zealous atheism renews some of the worst features of Christianity and Islam. Just as much as these religions, it is a project of universal conversion. Evangelical atheists never doubt that human life can be transformed if everyone accepts their view of things, and they are certain that one way of living - their own, suitably embellished - is right for everybody... It is a funny sort of humanism that condemns an impulse that is peculiarly human.

While we might associate such approaches with dramatically 'unreasonable' Marxist cases, such as those of the Shining Path and the Khmer Rouge (see Weinberg and Pedahzur, 2004, 1), Gray harbours serious concerns about forms of liberalism which are, consciously or unconsciously, perfectionist and comprehensive (see Gray, 2015) by virtue of their fetishising economism, individualism and wealth at the expense of the fact of pluralism and well-being (see Gray 2002, 92).

Beyond monotheism and atheism, there is scarce discussion of polytheism in the literature on fundamentalism. This may be because polytheists or animists are, by their very nature, more amenable to difference philosophically through the co-existence of deities, and the relationship between particular people and particular deities, or become 'unreasonable' (see the case of Hinduism in Ram-Prasad 1993) only within the context of states not fully shaped by reasonableness as reciprocity, in which the monopolisation of power becomes not just attractive, but imperative due to zero-sum contestations with other groups.

The point, here, is that the anthropological and sociological literature suggests that there are philosophical features of comprehensive doctrines that appear to predispose particular, 
monist groups to political unreasonableness. This predisposition is either ever present or inert, ready to lead a group to 'bad fundamentalism'/'extremism' when particular contextual considerations, such as the acquisition of power by unbelievers, emerge. Indeed, the social psychological literature on fundamentalisms indicates that those drawn to 'fundamentalist' doctrines may necessarily be predisposed to using philosophical unreasonableness to foment unreasonable political action. For example, Religious fundamentalism, dogmatism, and radicalisms: internal dynamics and social regulation (2008-2013) has shown that the abstract deontology of fundamentalisms can appeal to those with authoritarian dispositions, leading to forms of political praxis detrimental to the lives of others - even those proximate to the believers (Van Pachterbeke, Freyer and Saroglou 2011, 898).

While this calls into question Žižek's distinction between 'good' and 'bad' fundamentalisms, adopting a more comprehensive approach grounded, for example, in revealing the 'truth of pluralism' is not without difficulty. Indeed, in support of Žižek, the anthropological and sociological literature highlights the way in which challenges to philosophical unreasonableness have the capacity to push groups towards political unreasonableness. The authors of The Fundamentalism Project (1987-1995) argue that such doctrines seem necessarily to be triggered into political action by modernity as they pursue a prior Golden Age lost like in The Fall (see Freeden and Vincent, 2013, 13). There is often belief in scriptural authenticity and purity that seems at odds with the chaos of modernity (see Marty, 1996, 29). Challenging groups philosophically may stimulate such belief.

Indeed, Gray provides some support for such a position, arguing that fundamentalism is not a response to modernity, but its embodiment (Gray, 2015), with 'Al Qaeda's "pre-modern values" enabling 'it to operate very effectively in conditions of globalisation' (Gray, 2004a, 80). Gray's position runs parallel to that of Lawrence (1995), who has argued that fundamentalists despise modernism - synonymous with the expansion of individual autonomy and the confrontation with difference -, but use modernity - the increase in complexity of communication and rationality of bureaucracy -, to pursue their ends. Anthropologists, such as Nagata (2001, 494-495) have articulated this as a quest for certainty, with Haynes (1995, 22; see also Macedo 1995, 469) stating that 'Contemporary religious militancy ("fundamentalism") is rooted in the failed promise of modernity, invariably reactive against unwelcome manifestations of modernization, such as poverty, marginalization, insecurity and so on'. As Marty $(1988,25)$ puts it, 'fundamentalists feel that their heritages have been overlooked, derided, misunderstood, or opposed', referring to human goods, such as esteem and security, which are at the heart of Gray's value pluralism. Fundamentalist responses are distinctive insofar as they seek, in Emerson and Hartman's $(2006,128)$ terms, to 'remystify' and 'resist demystification' processes associated with modernity, paradoxically providing certainty and security through the esoteric. As Dorraj $(1999,235)$ puts it, 'The new religious revival is not simply a revival of the old, but the traditionalization of modernity as it is experienced by groups who either materially or spiritually have become marginalised by its effects'. This is apparent in ISIS's otherwise bizarre actions in Syria. In What ISIS Really Wants, Wood (2015) has forcefully argued that ISIS is very Islamic: 'the religion preached by its most ardent followers derives from coherent and even learned interpretations of Islam'. It is grounded in obsessive concern for intricate theological engagement, using tactics advocated in esoteric Qur'anic passages and hadiths to foment the 'end of days'. There is belief that, in a time of injustice (understood as inadequate adherence to the word of God), there is scope for believers to act with divine ordination to influence prophetic courses.

It is not clear, then, that a revelatory approach can avoid propelling some towards political unreasonableness. However, given that the literature suggests that the modern world is, in and of itself, diffidence inducing, it is even less clear that refraining from challenging philosophical unreasonableness is sustainable. There is evidence from a range of literatures to 
grant scepticism to the 'good'/'bad' 'fundamentalism'/'extremism' distinction, suggesting that Žižek's more limited approach at fostering political reasonableness fails to recognise the importance of disabusing the philosophical basis of unreasonableness. This is becoming apparent with regard to Saudi support for, and liberal governmental toleration of, Wahabbism insofar as evidence suggests that believers' contempt for non-believers often leads to militant action, irrespective of the intentions of Wahabbis themselves (see Wintour 2017; Corfe 2013, 63). As such, it may be that we have to accept that 'disparate burdens fall on proponents of totalistic religious or moral views', such as the Mozert parents, since 'We must not forget how such people would behave if they had political power' (Macedo 1995, 484). In this respect, we need to remember that alternative modus vivendi, such as the oft-vaunted Ottoman millet system (see Kymlicka 1995, 157), are governed unashamedly by the dominance of a particular comprehensive doctrine and grace and favour (revocable) toleration of other selected groups.

As such, if the concern is for upholding public reason, there seems to be reason to endorse more comprehensive efforts to challenge the philosophical bases of unreasonableness among particular groups, even if they appear to be 'good' fundamentalists. While the potential for alienating the philosophically unreasonable is significant, there are good reasons to believe that challenging philosophical unreasonableness is, perhaps, unavoidable. In this sense, we need only consider the way in which many Anglicans in the UK appear gradually to have become more attuned to the 'truth of pluralism' (see discussion in Fabricant 2017) by virtue of extended exposure to public criticism (see Dormor, McDonald and Caddick 2005).

\section{Conclusion: the challenge for liberals; the quandary for non-liberals}

That critics of liberalism, such as Gray and Žižek, develop accounts of fundamentalism grounded in public reason as reciprocity makes sense. Put simply, doctrines that reject the possibility of co-existing with others are intrinsically problematic for modern, pluralistic societies and, despite their criticisms of liberalism, Gray and Žižek do not seek to undermine the notion, if not the breadth, of pluralism itself. As such, there are good grounds for nonliberals to recognise openly that there is value in reason as reciprocity.

However, Gray's and Žižek's work also has significant implications for liberals. Unintentionally, by advancing positions on fundamentalism derived from or compatible with public reason, they highlight the limitations of liberal approaches. Put simply, their accounts indicate that liberalism can uphold much more modest forms of pluralism than suggested by political liberals. This has, of course, been a core ideological critique raised by Marxists, such as Marcuse (1965), who have argued that liberalism can claim to accommodate diversity only superficially since structures of capital, market and class render (consciously) excluded ways of life unviable. When liberal societies have been challenged substantively, they have responded by withdrawing the very freedoms that underpin liberalism, such as freedom of speech. We need only observe responses to Islamic 'extremism' to see this in action. As such, there is good reason for liberals to acknowledge that, in practice, liberalism is more comprehensive than presented by proponents of 'political' forms and that the empirical research examined above indicates that comprehensive responses may be unavoidable.

Similarly, critics of liberalism ought to acknowledge that their own approaches may not admit of greater pluralism. This is apparent in Marcuse's own belief in the necessity of a coercive, revolutionary minority, which sits uneasily with modern Marxists who have sought to eschew, for example, the cultural chauvinism apparent in Marx himself (see Avineri 1969). However, critics of liberalism may be less constrained by commitment to diffidence-inducing features of modernity and more able to adopt comprehensive approaches aimed at disabusing philosophical unreasonableness and creating institutions and resources to satisfy needs. In that regard, critics of liberalism may rightly suggest that reason as reciprocity can form successfully the basis for co-existence only in a society in which non-fundamentalist bases of grievance, 
such as poverty, inequality and alienation are overcome. Both Gray and Žižek are surely correct to argue that such a condition is beyond the scope of societies committed to neoliberal doctrines that regard any public interference in the economy as coercive. In that respect, there may be significant scope for critics of liberalism to engage more fully with perfectionist liberals, such as Joseph Raz (1998, 43), who view respect for persons in terms of respecting people's capacity for rational thought, rather than their currently held views. Our argument here indicates that the challenges of fundamentalism can only be addressed through recognition both of that capacity for reason and of the need honestly to discuss means of promoting philosophical reasonableness.

\section{Notes on contributors}

Matthew Johnson is a Lecturer in Politics at Lancaster University.

Simon Mabon is Lecturer in International Relations at Lancaster University.

\section{ORCID}

Matthew Johnson 0000-0002-9987-7050

\section{Acknowledgements}

We wish to acknowledge the assistance of Paul Mortimer and Jacob Glenholmes in sourcing material for this article and the comments of Christopher Macleod and Sarah Marsden on earlier drafts.

\section{References}

Ammerman, Nancy T. 1987. Bible Believers. New Brunswick: Rutgers University Press.

Antoun, Richard. 2001. Understanding Fundamentalism. Walnut Creek: Altamira.

Avineri, Shlomo. 1969. Karl Marx. New York: Anchor.

Corfe, Richard. 2013. The Democratic Imperative. Bury St Edmonds: Arena.

Berlin, Isaiah. 2002. Four Essays on Liberty. London: Oxford University Press.

Dormor, Duncan, Jack McDonald and Jeremy Caddick. 2005. "Introduction." In Anglicanism:

The Answer to Modernity, edited by Duncan Dormor, Jack McDonald and Jeremy Caddick, 1-16. London: Continuum.

Dorraj, Manochehr. 1999. "The Crisis of Modernity and Religious Revivalism." Social Compass 46: 225-240.

Emerson, Michael and David Hartman. 2006. "The Rise of Religious Fundamentalism." Annual Review of Sociology 32: 127-144.

Fabricant, Michael. 2017. "If the Church of England continues to smother liberal Anglicans, it is heading for a split." The Telegraph, February 16. http://www.telegraph.co.uk/news/2017/02/16/church-england-continues-smotherliberal-anglicans-heading-split/

Freeden, Michael and Andrew Vincent. 2013. "Introduction." In Comparative Political Thought, edited by Michael Freeden and Andrew Vincent, 1-23. Oxford: Routledge..

Galeotti, Anna-Elizabetta. 2002. Toleration as Recognition. Cambridge: Cambridge

University Press.

Gray, John. 1996. Mill on Liberty: A Defence. London: Routledge.

Gray, John. 1997. Endgames. Cambridge: Polity.

Gray, John. 2000. Two Faces of Liberalism. New York: Polity Press.

Gray, John. 2002. False Dawn. London: Granta.

Gray, John. 2003. Straw Dogs. London: Granta.

Gray, John. 2004a. Al Qaeda and What It Means to be Modern. London: Faber and Faber. 
Gray, John. 2004b. Heresies. London: Granta.

Gray, John. 2008. "The Atheist Delusion." The Guardian, March 15. http://www.theguardian.com/books/2008/mar/15/society

Haynes, Jeffery. 1995. "Religion Fundamentalism and Ethnicity." UNRISD Discussion Paper 65. Geneva: UNRISD.

Horton, John. 1996. "Toleration as a Virtue." In Toleration, edited by D Heyd, 28-43. Princeton: Princeton University Press.

Johnson, Matthew. T. 2012. "Progress, Anti-isms and Revolutionary Subjects." In The Legacy of Marxism, edited by M. Johnson, 57-74. New York: Continuum.

Johnson, Matthew. T. 2013. Evaluating Culture. Basingstoke: Palgrave Macmillan.

Jones, Peter. N. 2006. "Toleration, Value Pluralism, and the Fact of Pluralism." CRISPP 9: 189-210.

Kant, Immanuel. 1991. Political Writings. Cambridge: Cambridge University Press.

Kant, Immanuel. 2005. Groundwork for the Metaphysic of Morals. Abingdon: Routledge.

Kaplan, Lawrence. 1992. "Introduction." In Fundamentalism In: Comparative Perspective, edited by Lawrence Kaplan, 3-14. Amherst MA: University of Massachusetts Press..

Kelly, Erin and McPherson, Lionel. 2001. "On Tolerating the Unreasonable." Journal of Political Philosophy 9: 38-55.

Kippenberg, Hans. 1991. "Revolt against Modernism.” Numen 38: 128-133.

Kymlicka, Will. 1995. Multicultural Citizenship. Oxford: Oxford University Press.

Lawrence, Bruce. B. 1995. Defenders of God. Columbia: University of South Carolina Press.

Lincoln, Bruce. 2006. Holy Terrors. Chicago: University of Chicago Press.

Locke, John. 1689. A Letter Concerning Toleration. Indianapolis: Hackett.

Locke, John. 1988. Two Treatises of Government. Cambridge: Cambridge University Press.

Macedo, Stephen. 1995. "Liberal Civic Education and Religious Fundamentalism." Ethics 105: 468-496.

Marcuse, Herbert. (1965) "Repressive tolerance." In A Critique of Pure Tolerance, edited by R. P. Wolff, B. Moore and H. Marcuse, 81-123. Boston: Beacon.

Marty, Martin. 1988. "Fundamentalism as a Social Phenomenon." Bulletin of the American Academy of Arts and Sciences 42: 15-29.

Marx, Karl. and Friedrich Engels. 1974. The German Ideology. London: Lawrence and Wishart.

Masalha, Nur and Michael Hayes. 2006. "A Comparative Study of Jewish Christian and Islamic Fundamentalist Perspectives on Jerusalem." Holy Land Studies 4: 97-112.

Meyer, Thomas. 2001. "A fundamental fallacy." Times Higher Education Supplement, November 9. https://www.timeshighereducation.co.uk/features/a-fundamentalfallacy/165707.article.

Nagata, Judith. 2001. "Beyond Theology.” American Anthropologist 103: 481-498.

Quong, Jonathan. 2011. Liberalism without Perfection. New York: Oxford University Press.

Quong, Jonathan. 2013. "Public Reason." In The Stanford Encyclopedia of Philosophy, edited by E. N. Zalta. https://plato.stanford.edu/archives/sum2013/entries/public-reason.

Ram-Prasad, C. 1993. "Hindutva ideology." Contemporary South Asia 2: 285-309.

Rawls, John. [1971] 2001. "Justice as Reciprocity." In Collected Papers, edited by S Freeman, 190-224. Cambridge: Harvard University Press..

Rawls, John. [1975] 2001. “A Kantian Conception of Equality.” In Collected Papers, edited by S Freeman, 254-266. Cambridge: Harvard University Press.

Rawls, John. [1988] 2001. "The Priority of Right and Ideas of the Good." In Collected Papers, edited by S. Freeman, 449-472. Cambridge: Harvard University Press. 
Rawls, John. [1993] 2001. "The Law of Peoples." In Collected Papers, edited by S. Freeman, 529-564. Cambridge: Harvard University Press..

Rawls, John. 1996. Political Liberalism. New York: Columbia University Press.

Rawls, John. 1999. A Theory of Justice. Oxford: Oxford University Press.

Rawls, John. 2001. The Law of Peoples. Cambridge: Harvard University Press.

Raz, Joseph. 1986. "Disagreement in politics.” American Journal of Jurisprudence 43: 25-52.

Richards, Jeffery. 1979. The Popes and the Papacy In the Early Middle Ages 476-752. London: Routledge.

Van Pachterbeke, Matthieu, Christopher Freyer and Vassilis Saroglou. 2011. "When authoritarianism meets religion." European Journal of Social Psychology 41: 898-903.

Weinberg, Leonard and Ami Pedahzur. 2004. "Introduction." In Religious Fundamentalism and Political Extremism, edited by Leonard Weinberg and Ami Pedahzur, 1-10. New York: Psychology Press.

Wintour, Patrick. 2017. "Saudi Arabia boosting extremism in Europe, says former ambassador." The Guardian, July 13. https://www.theguardian.com/world/2017/jul/13/saudi-arabia-boosting-extremism-ineurope-says-former-ambassador.

Wood, Graeme. 2014. "The Three Types of People Who Fight for ISIS." New Republic, September 11. http://www.newrepublic.com/article/119395/isiss-three-types-fighters.

Wood, Graeme. 2015. "What ISIS Really Wants." The Atlantic. http://www.theatlantic.com/features/archive/2015/02/what-isis-really-wants/384980.

Žižek, Slavoj. 2008. In Defence of Lost Causes. London: Verso.

Žižek, Slavoj. $\quad$ 2013a. An Fundamentalism.https://www.youtube.com/watch?v=gepH1XVcVMg.

Žižek, Slavoj. 2013b. "Why the free market fundamentalists believe 2013 will be the best year ever." The Guardian, 17. http://www.theguardian.com/commentisfree/2013/feb/17/free-marketfundamentalists-think-2013-best.

Žižek, Slavoj. 2014. "ISIS Is a Disgrace to True Fundamentalism." The New York Times, September 3. http://opinionator.blogs.nytimes.com/2014/09/03/isis-is-a-disgrace-totrue-fundamentalism/?_r=0.

Žižek, Slavoj. 2015. "In the Wake of Paris Attacks the Left Must Embrace Its Radical Western Roots." In These Times, November 16. http://inthesetimes.com/article/18605/breakingthe-taboos-in-the-wake-of-paris-attacks-the-left-must-embrace-its. 